\title{
Is The Euro A Harbinger Of A World Currency?
}

William Horton, Sam Houston State University, USA

Hadley Leavell, Sam Houston State University, USA

Balasundram Maniam, Sam Houston State University, USA

\begin{abstract}
This paper speculated on the possibility or potential of a worldwide movement toward a single global currency using a study of the economic impact on the European Union (EU) of its single currency. Using the timeframe of the single currency adoption, three main factors of the EU were analyzed:1) the cost of living (inflation), 2) deficit spending, and 3) unemployment. It was hypothesized, for the sake of this study, that the effects on these three items would be roughly the same for the implementation of a single global currency. This assumption is based on the fact that the euro adoption was performed by countries whose economies and policies were not synchronized across-the-board in spite of the intention of the detailed treaty that foreshadowed the euro. A selective look at diverse literature perspectives touting both the achievements and downfalls of the euro adoption and implementation, news commentaries predicting the possibilities of further currency unification, and a brief history of currency, in general, was made. The finding of this study indicated that the euro did not appear to have a strong economic impact on its member countries based on the three criteria. That, coupled with the diversity of the world's nations in categories ranging from political to technical to financial, lead to the conclusion that a single world currency in the foreseeable future is unlikely.
\end{abstract}

Keywords: Currency; Euro; Dollar; Global Currency

\section{INTRODUCTION}

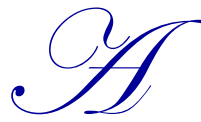
single global currency is an idea that conjures up a wide range of strong emotions, reactions, and opinions from otherwise seemingly rational individuals. Amegy Bank currency trader Cushing (2010) asserts, "It will never happen" citing too many political barriers and differences in national economies. Conversely, conspiracy theorists write that it is already happening under the control of secret organizations that have always strived to rule the world (Hole, 2010). Many Christians have believed for more than 2,000 years that a one-world currency is inevitable and is a sign of the end times based on a Biblical passage in the book of Revelation, Chapter 13, verses 16-18 (Winder, 2009).

The two main questions for this study are: 1) how feasible would it be to move a single global currency and 2) what would the economic impact be. Most of the basis for this research involves utilizing past experiences for the growth and adoption of Europe's currency. Specifically, the three economic factors related to the euro will be analyzed and a determination made of whether currency unification has any observable effect.

The first factor observed is inflation or cost of living. The question at hand is whether currency unification has a positive or negative effect on inflation or if it has any effect at all. The second area of concern is deficit spending. The adoption of the euro sought to reign in deficit spending to a manageable level. Did it succeed? Unemployment is the third area reviewed. European countries historically have a higher unemployment rate than the United States. The question addressed in this study is what effect currency unification has on unemployment rates. For all three questions, data is used from the European Central Bank. 
However, uncertainty is inherent in any discussion about a single global currency as it has two widely accepted meanings. The first meaning, and the one used herein, is the concept of a single global currency which would eliminate currency exchange difficulties and ease transactions worldwide. The second meaning relates to the idea of another prevailing currency replacing the dollar which is the standard global reserve currency presently in use by most developed nations.

\section{SUCCESS OR FAILURE: A REVIEW OF LITERATURE AND NEWS}

In an evaluation of a possible single global currency, one must look no farther than the recent union of several European currencies into the single euro. Although only in circulation for a little more than a decade, it took many years to implement and closely parallel the efforts needed to further unify current divergent world currencies. Since the unification leading to the euro has been in process for more than fifty years, much has been written on the subject, both prior to and since the euro was adopted on January 1, 1999.

The unification to the euro was looked upon unfavorably by some scholars. Prior to the euro's implementation, Dornbusch (1996) characterized the EMU (European Monetary Union) as a bad idea. Dornbusch, a Ford Professor of Economics and International Management at the Massachusetts Institute of Technology, cited Europe's lack of flexible wage and labor markets, mass unemployment, high deficits and vastly divergent countries that could not be treated the same. The words seem prophetic today after the financial crisis resulted from Euro Zone countries being allowed, undertaking large deficit spending.

Others have since praised the euro implementation as a monumental success. Cyr (2003) touted the success of the euro several years after its acceptance by saying that although it took longer than expected - a decade between the Maastricht Treaty and the implementation of the new European currency - that the "experiment" has so far been successful. Cyr wrote that Europe now dealt with conflicts related to fiscal, monetary, technical, and legal policies rather than the wars that dominated policies over the past several centuries.

In spite of the prediction of failure, and regardless of the successes enjoyed by the euro, recent discussion has hinted at the possibility of the euro replacing the dollar as the international reserve currency. ABC News reported in February 2010 that Dominique Strauss-Kahn, then head of the International Monetary Fund (IMF), suggested that there is a need for an alternate for the dollar as the global reserve currency (Dunphy, 2010).

Conway (2009), an economics editor for the UK Telegraph, reported a similar sentiment from the UN Conference on Trade and Development. In a statement by the United Nations committee, it was noted that the current system that joins the world economy and capital rules is not working correctly. It was also stated that although China and Russia have recommended a similar idea, this was the first time a major multinational institution has made such a suggestion. The report went on to call for a new Bretton Woods-style system of managed international exchange rates. In 1944, the Bretton Woods conference set up a managed exchange rate system and established the International Monetary Fund and part of the current World Bank. The idea was to further open markets to trade and exchange by implementing common rules of capital.

\section{A SHORT 4,000 YEARS - BACKGROUND}

Currency dates back approximately 4,000 years to ancient Egypt where it was used as a form of receipt for stored grain. This concept of stored-value was used for more than 1,500 years. Around $500 \mathrm{BC}$, a collapse in the regional trading system introduced the idea that anything of perceived value was only as valuable as the credit of the institution that backed it (Bernstein, 2008).

Shortly after this collapse of what could be called the first regional bank, people began using ingots of copper to represent value. This led to a move from the idea of it having value to the metal actually carrying value. Thus, coins were minted and used for exchange. Once coins were being used almost globally, people quickly discovered the shortfalls of having to carry that much metal around with them to pay for purchases. This burden led to the introduction of deposit receipts where money is stored in a safe place and a bank note representing the amount of stored value is issued to the depositor. As paper money increased in popularity, and central banks formed, 
currency continued its movement from a representation of stored metal to the more modern concept of legal tender notes that were accepted for all debts public and private. Although many forms of currencies have come and gone over the last 4,000 years, the dollar is accepted as the world-wide reserve currency along with only a few other currencies considered global in nature.

One global currency that threatens the dollar's top rank is the euro. Its implementation has set the stage for not only unseating the dollar as the reserve currency; it has demonstrated that currency unification is possible. After World War II, the European Economic Community (EEC) was formed by European countries under the protection of the United States through NATO. In 1993, the EEC was renamed the European Community (EC). The primary goals of the EEC, and subsequently the EC, were to form a more tightly knit community economically and create a single market that crossed borders while still permitting the countries to maintain political autonomy. An underlying goal was to prevent another war in an area that had endured two major wars during a relatively short period of time (Cyr, 2003).

Led by Germany's reputation as the global champion of hard money, members of the EC sought to unify their disparate national currencies into a larger supranational currency, further tying their economies together (Dornbusch, 1996). The Maastricht agreement, signed in 1991, set the standards, thus paving the way for this currency unification. This treaty outlined the criteria under which joining countries must qualify institutions that would control the new currency and a timetable for implementation.

Mundell (2000) wrote about reducing the international monetary arena. He felt the euro, along with the U.S. dollar and Japanese yen, had created a tri-polar currency world.

\section{THE EURO AND ITS ECONOMIC IMPLICATIONS}

A single global currency seems to be an unrealistic goal at first. Although the unification to the euro demonstrates that disparate, autonomous nations can agree on a single currency, pitfalls are clearly a danger when treating every nation the same. Although the treaty, which eventually led to the euro, had goals for membership qualifications and ongoing metrics, the ranges have been repeatedly adjusted to tolerate variances by member countries.

Three economic measures, which are calculated by countries using the euro, can be analyzed to help project if the unification was successful and what that might mean for a future global currency. The metrics focused on are cost of living, deficit spending, and unemployment. A study of these measures is especially difficult when the transparency of the results may be suspect. As a starting point, an initial question is whether the numbers reported are an accurate reflection of reality. The legitimacy of these numbers might begin to answer the question, "Is it possible to move to a single global currency and what is the impact?"

The first economic measure to be reviewed is the cost of living. One can infer that inflation reflects the cost of living since inflation can be defined as the rise in price of a basket of goods from period to period. The ECB defines inflation as the HICP or the Harmonized Index of Consumer Prices. The HICP attempts to measure inflation in a comparable manner throughout euro-zone countries. Target inflation should be less than two percent a year according to the criterion set by member nations.

The specifics of inflation are best introduced with a news report on France published in 2007 in the U.K. Telegraph. Officially, reported European inflation was approximately two percent annually since 1999 (Samuel, 2007). The report reveals that their study found that the cost of thirty daily-use items by consumers has risen as much as eighty percent in the same time period. The press study scrutinized items such as bread, coffee, potatoes, and toothpaste.

Another controversial facet of the way the ECB measures inflation is that the HICP does not include the cost of owner-occupied housing. This seems counter-intuitive to the definition of measuring the cost of living as home ownership is such a significant expense. Data suggests that in 2004, inflation would have been 2.7 percent, rather than the 2.1 percent, if this component had been included (Dominguez, 2006). News reports and HICP 
composition notwithstanding, a simple statistical analysis was conducted on the monthly inflation data as reported by the ECB. The analysis suggests that the monetary unification has had the desired effect of lowering inflation close to the target of two percent in aggregate. One could extrapolate that a single global currency could also effectively control inflation world-wide.

Sample one of the dataset used contains 96 data points of monthly inflation data from the period of January 1991 through December 1998. Sample two spans the introduction of the euro in January 1999 until October 2010 and encompasses 142 data points. Although sample two contains 46 more data points than sample one, both datasets are large enough to infer an overall trend. It should be noted that the datasets have not been seasonably or workingday adjusted and both encompass an evolving makeup of countries participating in the monetary union.

As seen in Table 1, pre-euro average inflation was 2.6 percent where the post-euro average fell to just under 2 percent. The standard deviation, or a measure of the variability of data points, suggests a slightly tighter range after the monetary unification as well. Chart 1 demonstrates a line graph of the post-euro sample. Marked fluctuations during the last two years can most likely be attributed to the recent global financial turmoil.

Table 1: HICP $1999-2010$

\begin{tabular}{|l|r|r|}
\hline \multicolumn{1}{|c|}{} & Pre-Euro & Post-Euro \\
\cline { 2 - 3 } Average & 2.623958 & 1.976056 \\
\hline Standard Deviation & 0.986407 & 0.799107 \\
\hline Mininum & 0.8 & -0.6 \\
\hline Maximum & 5 & 4 \\
\hline Count & 96 & 142 \\
\hline
\end{tabular}

Source: ECB Statistical Data Warehouse

Chart 1: HICP $1999-2010$

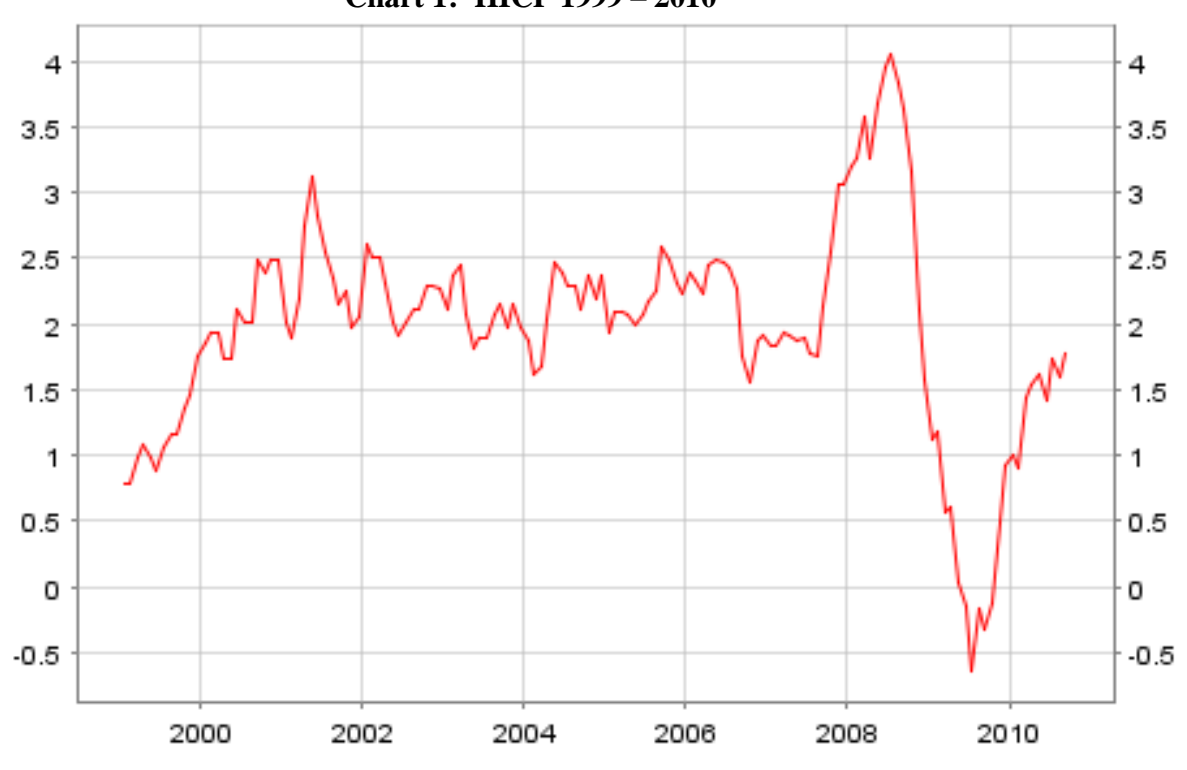

Source: ECB Statistical Data Warehouse

When looking to the euro as an example of the forecasted success of a single global currency, this vast range of outcomes leads to more questions than answers. One might expect that no country would entertain the idea of participating in currency unification if citizens expected everyday items would almost double in price over a five- 
year period. The question now is who to believe - is the data from the ECB correct or is the press study more accurate?

The second economic measure to be reviewed is deficit spending. Deficit spending is defined as the amount an entity's spending exceeds its income, when the entity spends more than it collects in taxes. For this economic measure, a review of the euro's effects on deficit spending will be made as well as an effort to ascertain if monetary unions can succeed in keeping deficits manageable. The EMU, through the terms of the Maastricht treaty, stipulates that the maximum level of deficit spending by member nations not exceed three percent of GDP. This constraint can be explicitly found in the Stability and Growth Pact that was adopted along with the single currency now in use across most of Europe.

As with inflation, it is important to see if a monetary union is effective in outlining and enforcing stability in deficit spending. The sample for this topic uses 46 data points reported quarterly, from the first quarter of 1999 through the second quarter of 2010. This data has not been seasonally or working-day adjusted and is from a fixed, 16-member set of nations. Table 2 shows that although the average deficit is within the three percent goal at 2.47706 percent, the standard deviation is quite high. The maximum reported deficit is two and one half times the goal at 8.04288 percent. Chart 2 shows that the 8 percent deficit is recent and can probably be attributed to the recent financial crisis; however, there are still several points of 4 and 5 percent deficits.

Table 2: Deficit/Surplus

\begin{tabular}{|l|r|}
\hline \multicolumn{1}{|l|}{} & Post-Euro \\
\cline { 2 - 2 } Average Deficit & -2.47706 \\
\hline Standard Deviation & 2.199382 \\
\hline Maximum Deficit & -8.04288 \\
\hline Maximum Surplus & 1.298385 \\
\hline Count & 46 \\
\hline
\end{tabular}

Chart 2: Deficit as a \% of GDP $1999-2010$

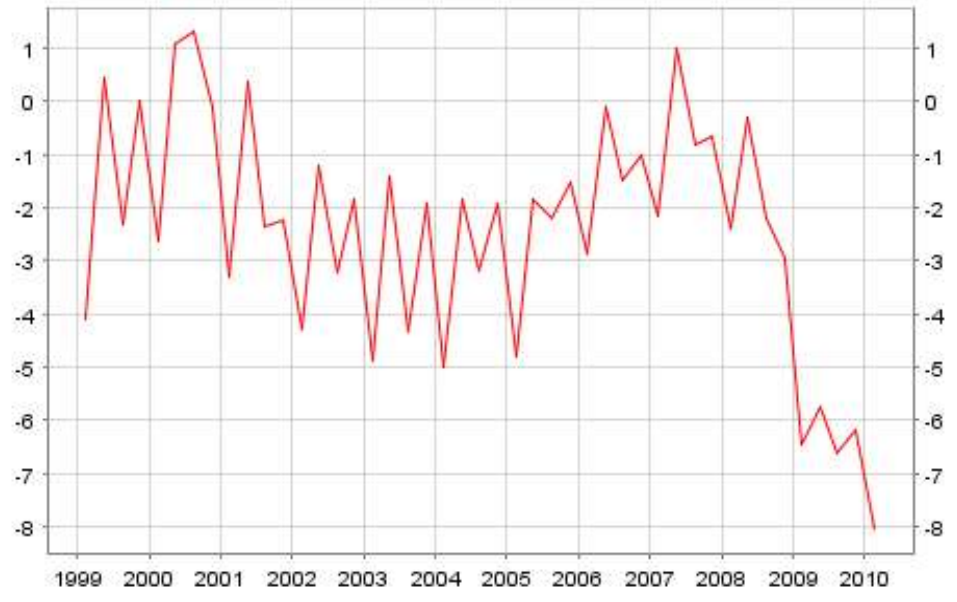

Source: ECB Statistical Data Warehouse

In a study published in the Eastern Economic Journal, the authors found that most European countries succeeded in lowering their deficits to near the 3 percent mark before the launch of the euro. That study attributed the reigning in of deficits to the strong political will that existed in Europe to move to a single currency (Arestis, Khan, \& Luintel, 2002). Interestingly, that study also found that even countries that did not participate in the adoption of the euro enjoyed stable and lower deficits. 
Taking into consideration the variability of the data since the euro implementation, along with previous research, it does not appear that a monetary union is very effective in controlling member nation deficit spending. Using the euro as an experiment, it is tough to conclude that global currency unification would be any more successful at limiting deficit spending. An important question could be whether a common currency can exist without common central government to mandate fiscal policy across all member states.

The third economic measure to be reviewed is unemployment. Unemployment in the United States has edged up to 9 percent (Bureau of Labor Statistics, 2010). The United States has historically enjoyed relatively low unemployment rates, while Europe has had slightly higher rates. In a comparison of pre- and post-euro implementation, data were again extracted from the ECB's own statistics. This data came from a fixed makeup of 16 countries and is seasonally adjusted, but not working-day adjusted. The pre-euro sample contains 48 data points reported monthly, from January 1995 through December 1998. Post-euro data contain 141 data points encompassing the period of January 1999 through September 2010.

A simple analysis reveals that, on average, unemployment has been slightly lower since the euro was implemented, falling from 10.42708 to 8.642908 percent, but with a slightly higher standard deviation. Another important observation is that the average is lower despite the past two years of approximately 10 percent unemployment. Table 3 summarizes the findings while Chart 3 shows the post-euro trend.

Table 3: Unemployment

\begin{tabular}{|l|r|r|}
\hline \multicolumn{1}{|c|}{} & Pre-Euro & Post-Euro \\
\hline Average & 10.42708 & 8.642908 \\
\hline Standard Deviation & 0.230457 & 0.732921 \\
\hline Mininum & 9.83 & 7.18 \\
\hline Maximum & 10.7 & 10.07 \\
\hline Count & 48 & 141 \\
\hline
\end{tabular}

Source: ECB Statistical Data Warehouse

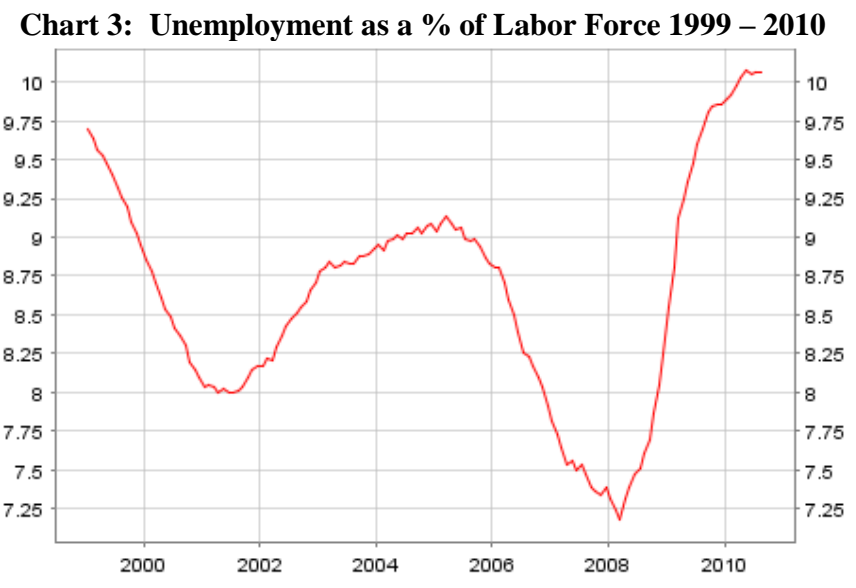

Source: ECB Statistical Data Warehouse

Unemployment does seem to have changed after the euro implementation, although there is no hard evidence to suggest that the monetary unification alone is responsible for the lower unemployment. Using only ECB data, it is difficult to determine how currency unification would affect countries that are even more disparate in nature and geography. 


\section{IMPLICATIONS FOR THE FUTURE}

Prior currency unification has taken several decades to complete. The unification leading to the introduction of the euro may be easier than global currency unification due to the proximity, size, and similarity of the primary countries involved. From an economic standpoint, there are several conclusions that we can draw from the euro example.

First, the euro implementation seems to have had very little effect on inflation, deficit spending, and overall unemployment. Although there are slight changes in each area and the ECB charter mandates compliance, it is not obvious that simply by moving to one currency, the desired outcome was achieved. These results can also be demonstrated in measuring data from the United Kingdom, a country that still sits on the euro sideline.

Conceivably larger sets of data and more independent data could help shed light on these impacts. Although the data-gathering and analyses would be both costly and time consuming, it should further narrow the gap found in reported inflation data. There is a noticeable difference in the way in which the ECB reports inflation and the method taken by the press study.

A second conclusion readily inferred by a study of the euro is that it did have positive implications on ease of trade and travel. No longer are consumers concerned with foreign money exchanges when moving from country to county or ending up with French Francs that they need to exchange back to Deutsche Marks. Another topic that warrants discussion is the limitations, or reality of global currency unification. One of the fundamental challenges to the euro was to implement a single currency while allowing member countries to remain largely autonomous. The ECB is viewed more as an addition to the original country institutions than an organization that is representative to the countries it serves.

Dominguez (2006) asserts that there has been little impact on Europe's economy due to the continued decentralization of decision-making and the manner in which those decisions are carried out. This decentralization is demonstrated by the mandated objective given to the ECB. Its primary objective is to keep price stability with a secondary goal of economic growth. This objective contrasts with the U.S. Federal Reserve's multiple equal objectives of price stability, full employment, and long-term interest rates maintenance. The issuance of currency, supervisory powers, and being the lender of last-resort authority are also elements which plague the ECB. While the central entity approves bank notes and coins, the technical aspects are left to the national banks. Both supervisory and lender of last-resort roles have traditionally been left to national banks.

Economics aside, there are several other implications not discussed in this review. Political control, financial impact, and disparate standards of living are just a few. Who would control a single global currency? What would the banking structure look like? How would a single currency affect poor countries or rich countries? These are all topics that would need to be addressed before the world's nations could get close to agreeing on a single currency.

\section{SUMMARY}

Although many European countries now share a currency, the unification both starts and ends with that currency and contains no other perceivable benefits from the economic topics discussed in this paper. A deeper look at financial factors and other economic topics, such as trade, might yield great benefits which override the limited view undertaken here.

This paper reviewed three possible indicators of the benefits of a single currency in the EU - inflation, unemployment, and deficits. Statistical analysis indicated that a single currency does not necessarily benefit the three indicators. A noted benefit of a single currency is related to commerce and travel within the countries using the currency. This single currency does improve business activity between countries as foreign exchange problems are eliminated. The same advantage carries through for tourism as well. 
In the case of the euro, many questions still need to be answered as to who actually controls the money and monetary policy. The Euro is relatively small compared to other currencies and moving to a single global currency is currently a farfetched idea.

\section{AUTHOR INFORMATION}

William Horton completed the Master of Business Administration program at Sam Houston State University in 2010. PO Box 2026, Huntsville, TX 77341. E-mail: fin_whl@shsu.edu

Hadley Leavell earned his DBA from Louisiana Tech in 1991. Currently he is a professor of finance at Sam Houston State University. PO Box 2026, Huntsville, TX 77341. E-mail: leavell@ shsu.edu (Corresponding author)

Balasundram Maniam is a professor of finance at Sam Houston State University. He obtained his Ph.D. in Finance from University of Mississippi in 1992. PO Box 2026, Huntsville, TX 77341. E-mail: gba bxm@shsu.edu

\section{REFERENCES}

1. Arestis, P., Khan, M., \& Luintel, K. B. (2002). Fiscal Deficits in Monetary Unions: A Comparison of EMU and United States. Eastern Economic Journal, 28 (1), 89-103.

2. $\quad$ Bernstein, P. (2008). A Primer on Money, Banking and Gold (3rd ed.). Hoboken, NJ: Wiley.

3. Bureau of Labor Statistics. (2010, January 12). United States Deparment of Labor. Retrieved October 30, 2010, from Labor Force Statistics from the Current Population Survey: http://www.bls.gov/cps/prev_yrs.htm

4. Bureau of Labor Statistics. Economic News Release (2011, May 6) Retrieved May 27, 2011 from the United States Department of Labor. http://www.bls.gov/news.release/empsit.nr0.htm

5. Conway, E. (2009, September 7). UN wants new global currency to replace dollar. Retrieved October 17, 2010, from Telegraph.co.uk: http://www.telegraph.co.uk/finance/currency/6152204/UN-wants-new-globalcurrency-to-replace-dollar.html

6. Cyr, A. I. (2003, October). The Euro: Faith, Hope and Parity. International Affairs (Royal Institute of International Affairs 1944-), 79 (5), pp. 979-992.

7. Dominguez, K. M. (2006). The European Central Bank, the Euro, and Global Financial Markets. The Journal of Economic Perspectives, 20 (4), 67-88.

8. $\quad$ Dornbusch, R. (1996). Euro Fantasies. Foreign Affairs, 75 (5), 110-124.

9. Dunphy, H. (2010, 226). Head of IMF Proposes New Reserve Currency. (A. News, Producer) Retrieved 10 17, 2010, from ABC News/Money: http://abcnews.go.com/Business/wireStory?id=9958995

10. Hole, R. (2010). True Conspiracies. Retrieved October 10, 2010, from http://www.trueconspiracies.com/

11. Mundell, R. A. (2000, June 3). A reconsideration of the twentieth century. American Economic Review, pp. 327-340.

12. Samuel, H. (2007, January 01). Telegraph World News. Retrieved 10 24, 2010, from Telegraph.co.uk: http://www.telegraph.co.uk/news/worldnews/1538304/Euro-blamed-for-rocketing-cost-of-living.html

13. Winder, J. G. (2009, April 2). Obama Set To Discuss “One World Currency" With China And Russia: End Times? Retrieved October 2010, 2010, from The Cypress Times: http://www.thecypresstimes.com/article/News/Opinion_Editorial/OBAMA_SET_TO_DISCUSS_ONE_W ORLD_CURRENCY_WITH_CHINA_AND_RUSSIA_END_TIMES/2151 